LOCKHEED MARTINA

ENVIRONMENTAL

RESTORATION

PROGRAM

\section{PROGRAM}

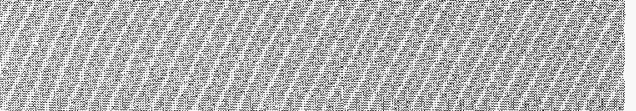

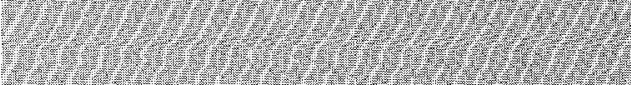

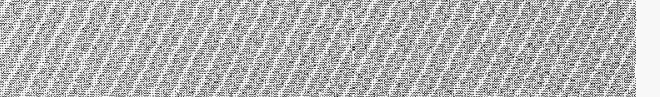

Ply

(1)

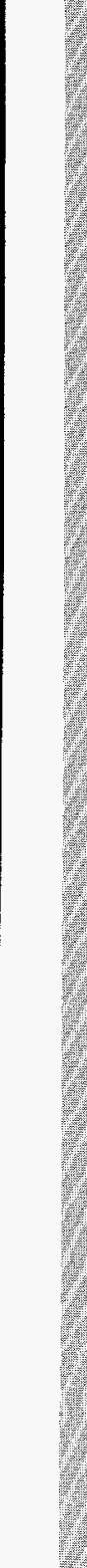

MANAGEDBY

LOCKHEED MARTIN ENERGY SYSTEMS, INC.

FOR THE UNITED STATES

DEPARTMENT OF ENERGY
RECEIVED

FEB $2^{9} 1996$

OSTI
ORNL/ER-300

\section{Work Plan for the Oak Ridge National Laboratory Groundwater Program: Continuous Groundwater Collection}



ORNL/ER-300

Energy Systems Environmental Restoration Program

ORNL Environmental Restoration Program

\title{
Work Plan for the Oak Ridge National Laboratory Groundwater Program: Continuous Groundwater Collection
}

Date Issued-August 1995

\section{DISCLAIMER}

This report was prepared as an account of work sponsored by an agency of the United States Government. Neither the United States Government nor any agency thereof, nor any of their employees, makes any warranty, express or implied, or assumes any legal liability or responsibility for the accuracy, completeness, or usefulness of any information, apparatus, product, or process disclosed, or represents that its use would not infringe privately owned rights. Reference herein to any specific commercial product, process, or service by trade name, trademark, manufacturer, or otherwise does not necessarily constitute or imply its endorsement, recommendation, or favoring by the United States Government or any agency thereof. The views and opinions of authors expressed herein do not necessarily state or reflect those of the United States Government or any agency thereof.

\author{
Prepared for \\ U.S. Department of Energy \\ Office of Environmental Management \\ under budget and reporting code EW 20 \\ Environmental Restoration and Waste Management Programs \\ OAK RIDGE NATIONAL LABORATORY \\ Oak Ridge, Tennessee 37831-8169 \\ managed by \\ LOCKHEED MARTIN ENERGY SYSTEMS, INC. \\ for the \\ U.S. DEPARTMENT OF ENERGY \\ under contract DE-AC05-84OR21400
}


APPROVAL PAGE

WORK PLAN FOR

THE OAK RIDGE NATIONAL LABORATORY GROUNDWATER PROGRAM: CONTINUOUS GROUNDWATER DATA COLLECTION

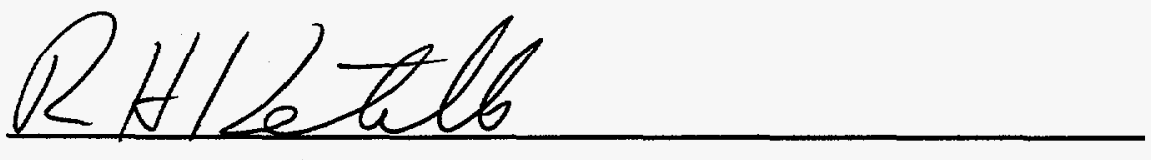

R. H. Ketelle, ORNL ER Area-Wide Groundwater Program Manager

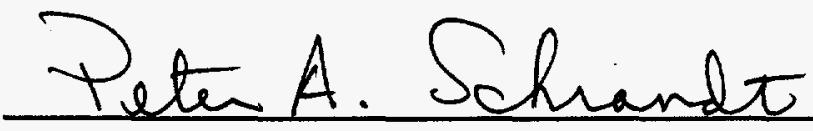

P. A. Schrandt, ORNL ER Quality Assurance Manager

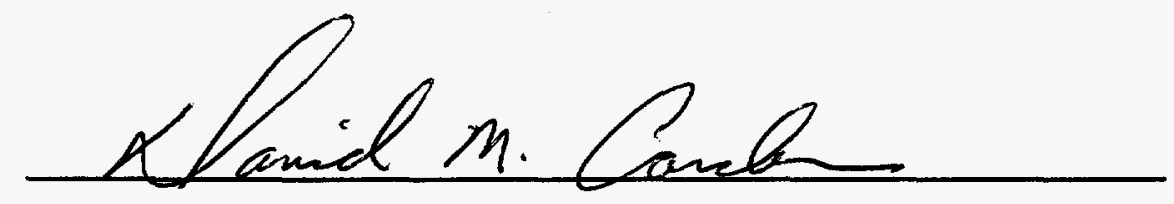

D. M. Garden, DOE ER QA/QC Specialist
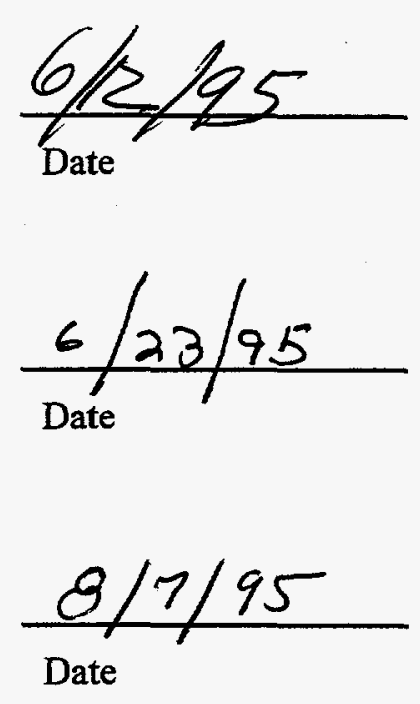

ii 


\section{CONTENTS}

FIGURES

TABLES

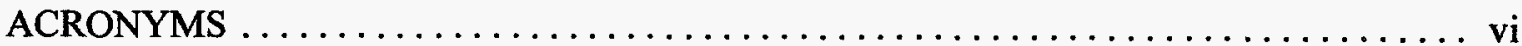

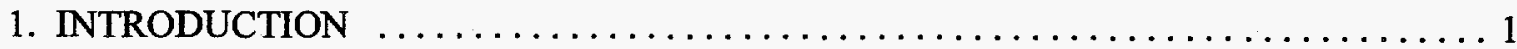

2. DATA NEEDS AND DATA QUALITY OBJECTIVES $\ldots \ldots \ldots \ldots \ldots \ldots \ldots \ldots \ldots 2$

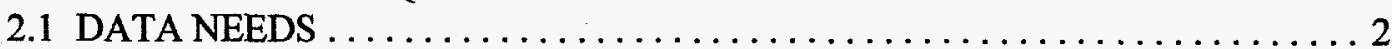

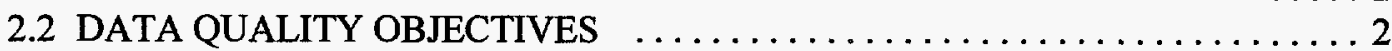

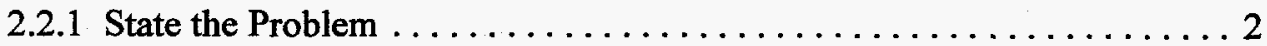

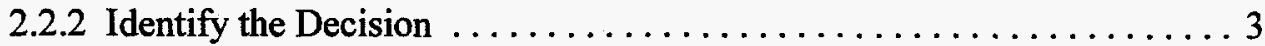

2.2.3 Identify the Inputs to the Decision $\ldots \ldots \ldots \ldots \ldots \ldots \ldots \ldots \ldots \ldots$

2.2.4 Define the Study Boundaries ................... 4

2.2.5 Develop a Decision Rule ..................... 4

2.2.6 Specify the Limits of Uncertainty $\ldots \ldots \ldots \ldots \ldots \ldots \ldots \ldots$

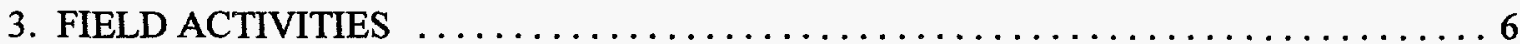

3.1 WELL DATA AND LOCATIONS $\ldots \ldots \ldots \ldots \ldots \ldots \ldots \ldots \ldots \ldots \ldots \ldots \ldots \ldots \ldots \ldots$

3.2 CONTINUOUS GROUNDWATER DATA COLLECTION $\ldots \ldots \ldots \ldots \ldots \ldots 6$

3.2.1 Well Monitoring Equipment $\ldots \ldots \ldots \ldots \ldots \ldots \ldots \ldots \ldots \ldots \ldots$

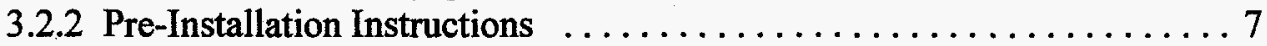

3.2.3 Installation Instructions $\ldots \ldots \ldots \ldots \ldots \ldots \ldots \ldots \ldots \ldots \ldots$

3.2 .4 Routine Service Instructions $\ldots \ldots \ldots \ldots \ldots \ldots \ldots \ldots \ldots \ldots$

3.2.5 Removal Instructions . . . . . . . . . . . . . . . . . . 9

3.3 FIELD DOCUMENTATION INSTRUCTIONS $\ldots \ldots \ldots \ldots \ldots \ldots \ldots \ldots \ldots$

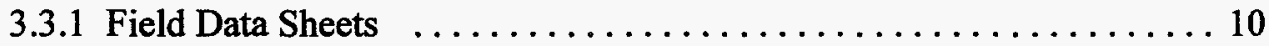

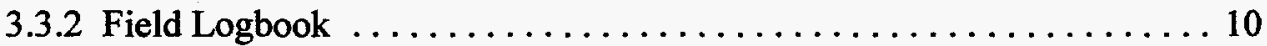

3.4 DATA LOGGER OPERATION AND FILE NAMING INSTRUCTIONS $\ldots \ldots$. 11

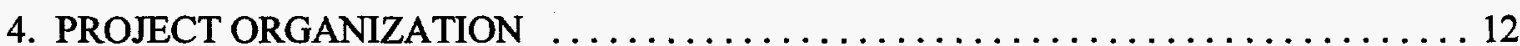

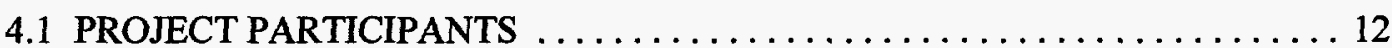

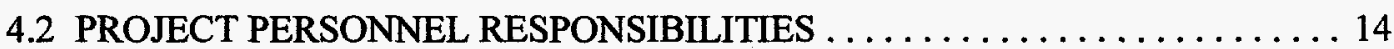

4.2.1 ORNL ER Area-Wide Groundwater Program Manager . . . . . . . . 14

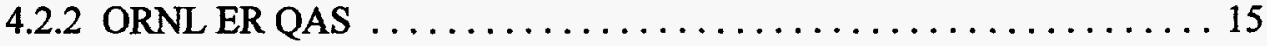

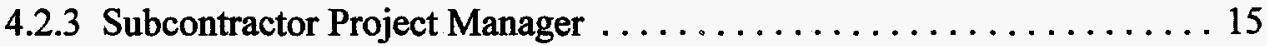

4.2.4 Subcontractor Field Team Leader $\ldots \ldots \ldots \ldots \ldots \ldots \ldots \ldots \ldots \ldots \ldots$

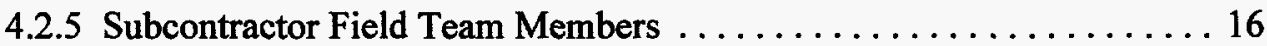

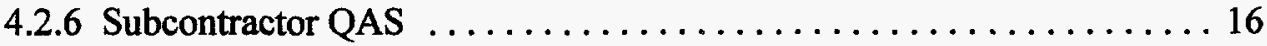




\section{CONTENTS (CONTINUED)}

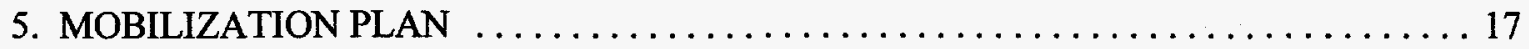

5.1 GENERAL TRAINING REQUIREMENTS $\ldots \ldots \ldots \ldots \ldots \ldots \ldots \ldots \ldots \ldots$

5.2 TASK-SPECIFIC TRAINING REQUIREMENTS $\ldots \ldots \ldots \ldots \ldots \ldots \ldots \ldots \ldots$

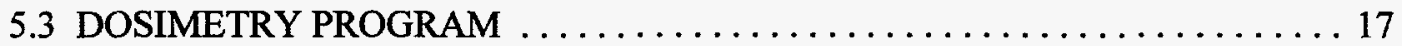

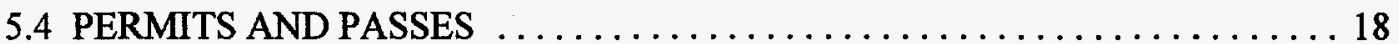

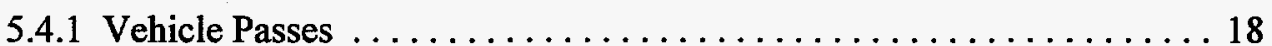

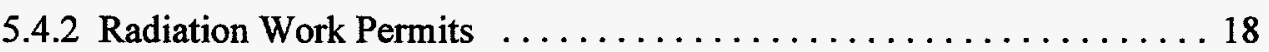

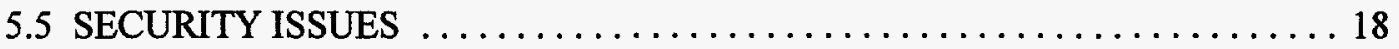

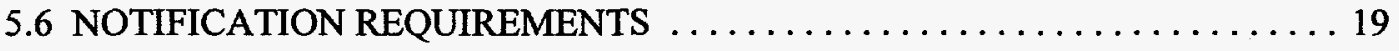

5.6.1 ORNL Lab Shift Superintendent $\ldots \ldots \ldots \ldots \ldots \ldots \ldots \ldots \ldots \ldots \ldots$

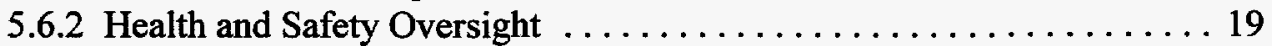

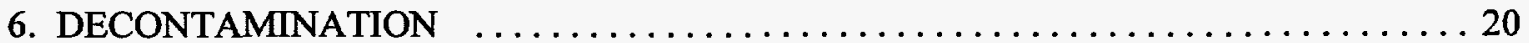

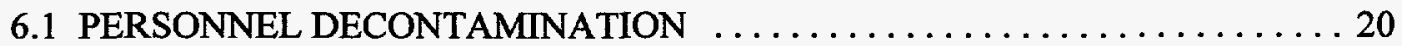

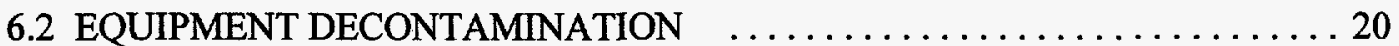

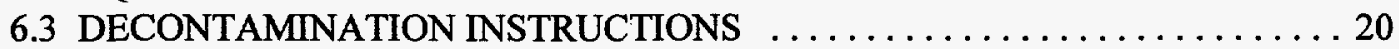

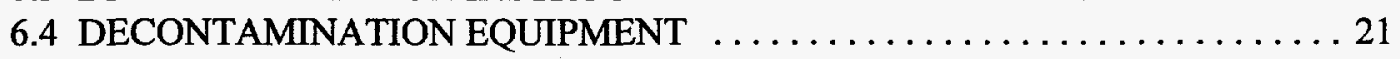

APPENDIX A: FIELD DATA SHEETS AND INSTRUCTIONS 


\section{FIGURES}

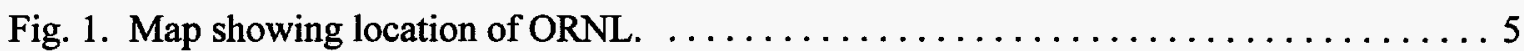

Fig. 2. Organizational structure of the ORNL Area-Wide monitoring efforts. $\ldots \ldots \ldots 13$

\section{TABLES}

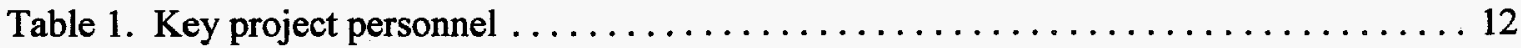

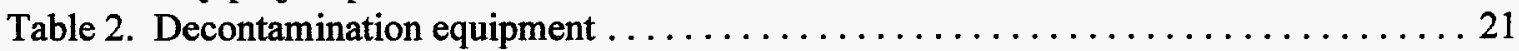




\section{ACRONYMS}

$\begin{array}{ll}\text { DOE } & \text { U.S. Department of Energy } \\ \text { DQO } & \begin{array}{l}\text { Data Quality Objectives } \\ \text { depth to water }\end{array} \\ \text { ER } & \text { Environmental Restoration } \\ \text { GET } & \text { General Employee Training } \\ \text { H\&SP } & \begin{array}{l}\text { Health and Safety Plan } \\ \text { HAZWOPER }\end{array} \\ \text { HP } & \begin{array}{l}\text { Heardous Waste Operations and Emergency Response } \\ \text { IFDS }\end{array} \\ \text { IH } & \begin{array}{l}\text { Installation Field Data Sheet } \\ \text { Industrial Hygiene }\end{array} \\ \text { LMES } & \begin{array}{l}\text { Lockheed Martin Energy Systems, Inc. } \\ \text { LSS }\end{array} \\ \text { Lab Shift Superintendent } \\ \text { MMES } & \begin{array}{l}\text { Martin Marietta Energy Systems, Inc. } \\ \text { mean sea level }\end{array} \\ \text { MSL } & \text { Oak Ridge National Laboratory } \\ \text { ORNL } & \text { Waste Area Group } \\ \text { Wh } & \text { Work Plan }\end{array}$




\section{INTRODUCTION}

The continuous collection of groundwater data is a basic and necessary part of Lockheed Martin Energy Systems', Inc. (LMES) $)^{*}$ Oak Ridge National Laboratory (ORNL) Environmental Restoration (ER) Area-Wide Groundwater Program. Continuous groundwater data consist primarily of continually recorded groundwater levels, and in some instances, specific conductivity, $\mathrm{pH}$, and/or temperature measurements. These data will be collected throughout the ORNL site. This Work Plan (WP) addresses the technical objectives, equipment requirements, procedures, documentation requirements, and technical instructions for the acquisition of the continuous groundwater data.

The intent of this WP is to provide an approved document that meets all the necessary requirements while retaining the flexibility necessary to effectively address ORNL's groundwater problems. Although significant advances have been made, groundwater behavior at many ORNL locations is not well understood. Many times, groundwater conditions are such that important information can be learned, provided data are collected. Unfortunately, it is not always foreseeable that this information can be learned prior to the window of opportunity for collecting the data. Since both the time frame for document preparation, comment, revision, and approval and the time frame for task delineation, contracting, and procurement may exceed this window of opportunity, flexibility in an approved WP is critical. Groundwater scientists need the ability to make technical decisions and expedite action on those decisions in a timely manner. The primary flexibility needed is the ability to move monitoring equipment from one well or piezometer to another in a timely manner.

Continuous groundwater monitoring furthers the understanding of the interaction between the groundwater system and the hydraulics of waste burial trenches and other anthropogenic features (storm drains, waste impoundments, etc.). Also, monitoring data are needed to evaluate the hydrological response of the groundwater system to precipitation events and to identify groundwater and burial trench groundwater flow pathways. As previously stated, groundwater monitoring data are basic and essential elements needed for groundwater scientists to address groundwater flow and contaminant transport problems.

This document addresses the technical aspects of collecting continuous groundwater data. This WP is only one part of the documentation needed to collect groundwater data. Other documents including a Quality Assurance Project Plan (QAPjP), Health and Safety Plan (H\&SP) and a Data Management Plan are also required.

"Formerly Martin Marietta Energy Systems, Inc. (MMES). 


\section{DATA NEEDS AND DATA QUALITY OBJECTIVES}

\subsection{DATA NEEDS}

This section presents the data needs as identified by the ORNL ER Area-Wide Groundwater Program with respect to the collection of continuous groundwater monitoring data. Continuous groundwater monitoring data are needed for assessing the generation and transport of contaminated groundwater. A critical need by groundwater scientists is flexibility in an approved WP so that water level monitoring efforts can rapidly respond as new information is learned, as windows of opportunity for important data collection present themselves, or as conditions change. The primary flexibility need is the ability for groundwater monitoring equipment to be readily moved from one well or piezometer to another without revising program and project-specific documentation.

\subsection{DATA QUALITY OBJECTIVES}

This project is not mandated by CERCLA, therefore no formalized meetings for data quality objective (DQO) development were held. Internally, DQOs were generated by the project team based on the end uses of the data to be collected.

DQOs are qualitative and quantitative specifications used to design a study that will limit uncertainty to an acceptable level. The DQO process is a systematic planning process for ensuring that environmental variability and analytical quantitative requirements are considered. Since sampling and analysis are not involved in the efforts described by this document, analytical requirements are not applicable. The DQO process has a logical structure that focusses planning on the intended use of the data. The DQO process entails seven steps which are presented below.

\subsubsection{State the Problem}

The problem is that when groundwater contacts buried wastes, the groundwater becomes contaminated. The contaminated groundwater may move off-site, creating risk to human health and the environment. Contaminated groundwater is generated when the level (elevation) of groundwater exceeds that of buried wastes. The contaminants can then move off-site provided there is sufficient hydrological gradient (the change in water elevation over a distance). When assessing the risk to human health and the environment and the remedial measures to mitigate this problem, scientists, ER managers, regulators, and other decision makers need to understand both the generation and the transport mechanisms of groundwater contamination.

Many factors need to be understood to assess this problem. Residence time (the duration in which groundwater contacts buried wastes), the type and concentration of contaminants, the attenuation and retardation factors affecting transport, and a host of other chemical and physical factors vary in importance from one location to another depending on the hydrogeological environment. The most basic and universally important data however, directly related to both the generation and transport of contaminants, are water levels and the transient response of water levels to weather and climatic events within and around waste burial areas.

Continuous groundwater monitoring data are routinely collected at the ORNL site as part of regulatory compliance; however, these routine efforts may not meet the needs of decision makers. This WP is designed to provide a mechanism to meet these needs. 
This WP primarily addresses one data collection element, continuous monitoring of water levels. Of secondary importance, this WP also addresses the continuous collection of $\mathrm{pH}$, specific conductivity, and temperature data. Collection of the $\mathrm{pH}$, specific conductivity, and temperature data are sometimes critical and represent virtually insignificant added costs when collected in conjunction with water level data.

\subsubsection{Identify the Decision}

The primary focuses and decisions of ORNL ER activities concerning contaminated groundwater are:

- to prioritize the WAGs based on risk to human health and the environment;

- to prioritize remedial actions within individual WAGs based on potential risk reduction, cost, and performance;

- to determine the nature and duration of water-waste contact (generation of contaminated groundwater);

- to determine contaminant flow pathways (transport of contaminated groundwater); and

- to evaluate changes in risk resulting from implementation of remedial measures (performance evaluation).

This WP does not address all data that may be needed to make the above prioritizations, determinations, and evaluations. However, decisions will be made using the continuous monitoring data.

\subsubsection{Identify the Inputs to the Decision}

Continuously recorded groundwater level and/or $\mathrm{pH}$, temperature, and specific conductivity data are some of the inputs to the decision. This continuous groundwater monitoring data will be one of the many inputs to the decisions. Other data elements (inputs to the decision) are beyond the scope of this WP.

The DQO process is iterative and therefore requires iterative input to the decision. This paradigm will be applied to this effort because antecedent groundwater and meteorological conditions are, by definition, always different at two different points in time. Collection of monitoring data at one location during several different points in time is probable and should be expected.

Once the hydrological response at a certain location is believed to be understood and/or the hydrological response at another location becomes more important to data users, monitoring equipment may be moved to another location. It is important to note that some groundwater monitoring locations may need to be reoccupied even after the hydrological response at that location was believed to be known. 


\subsubsection{Define the Study Boundaries}

The spatial boundary of the study area is the ORNL site depicted in Fig. 1. The depth of investigation is variable but is generally confined to the upper few hundred feet below ground surface. Temporally, these data need to be collected on a continuous basis throughout the expected duration of the ORNL ER Area-Wide Groundwater Program activities. Beyond this time frame, continuous groundwater data collection may continue although probably under a different program or plan.

\subsubsection{Develop a Decision Rule}

The results of this study will identify where wastes are in contact with groundwater within WAGs and where hydrogeological conditions allow for the transport of contaminants from the WAGs. Based on this and other information, a prioritization can be made as to which WAGs or areas of WAGs present the highest risk, and the feasibility of remedial actions to reduce risk can be evaluated. The monitoring data collected by the efforts presented in this WP must be used with other data to make this prioritization.

The efforts described in this WP are only one element that will be used in decision making. It is likely that the outcome of risk determination will impact the level of this effort. For example, in the event of no-action determinations, the long-term level of effort for groundwater monitoring will probably be reduced in frequency or number of locations. However, for "take action" scenarios, groundwater monitoring efforts will probably need to increase in order to fully support feasibility studies, engineering, and to evaluate the impact of remedial actions.

\subsubsection{Specify the Limits of Uncertainty}

Varied levels of uncertainty in continuous groundwater monitoring data are expected and will not significantly impact the risk or assessment of risk to human health or the environment from groundwater contamination. However, other data, such as groundwater sampling results, impact calculated risk values significantly. High levels of uncertainty in groundwater monitoring data of the type delineated by this WP is not a common occurrence.

In order to maintain long-term flexibility in this WP, it is important not to specify acceptable levels of uncertainty in the data based on a particular manufacturer's specifications. Equipment used for the continuous monitoring efforts will change over time due to wear, replacement, and data needs. In general, water level monitoring equipment is precise to $\pm 0.01 \mathrm{ft}$ and accurate to within $\pm 0.10 \mathrm{ft}$ with respect to the surveyed elevations of the well. Measurements of PH data are generally precise to $\pm 0.02 \mathrm{pH}$ units and accurate to $\pm 0.5 \mathrm{pH}$ units. Specific conductivity is accurate to a percent range of the full scale of the instrument, usually $\pm 3 \%$ of full scale. For ORNL groundwater, this implies a precision of $\pm 10 \mu \mathrm{S} / \mathrm{cm}$ and an accuracy of 25 to $50 \mu \mathrm{S} / \mathrm{cm}$. Temperature sensors are generally precise to $\pm 0.1^{\circ} \mathrm{C}$ and accurate to $\pm 0.5^{\circ} \mathrm{C}$. 


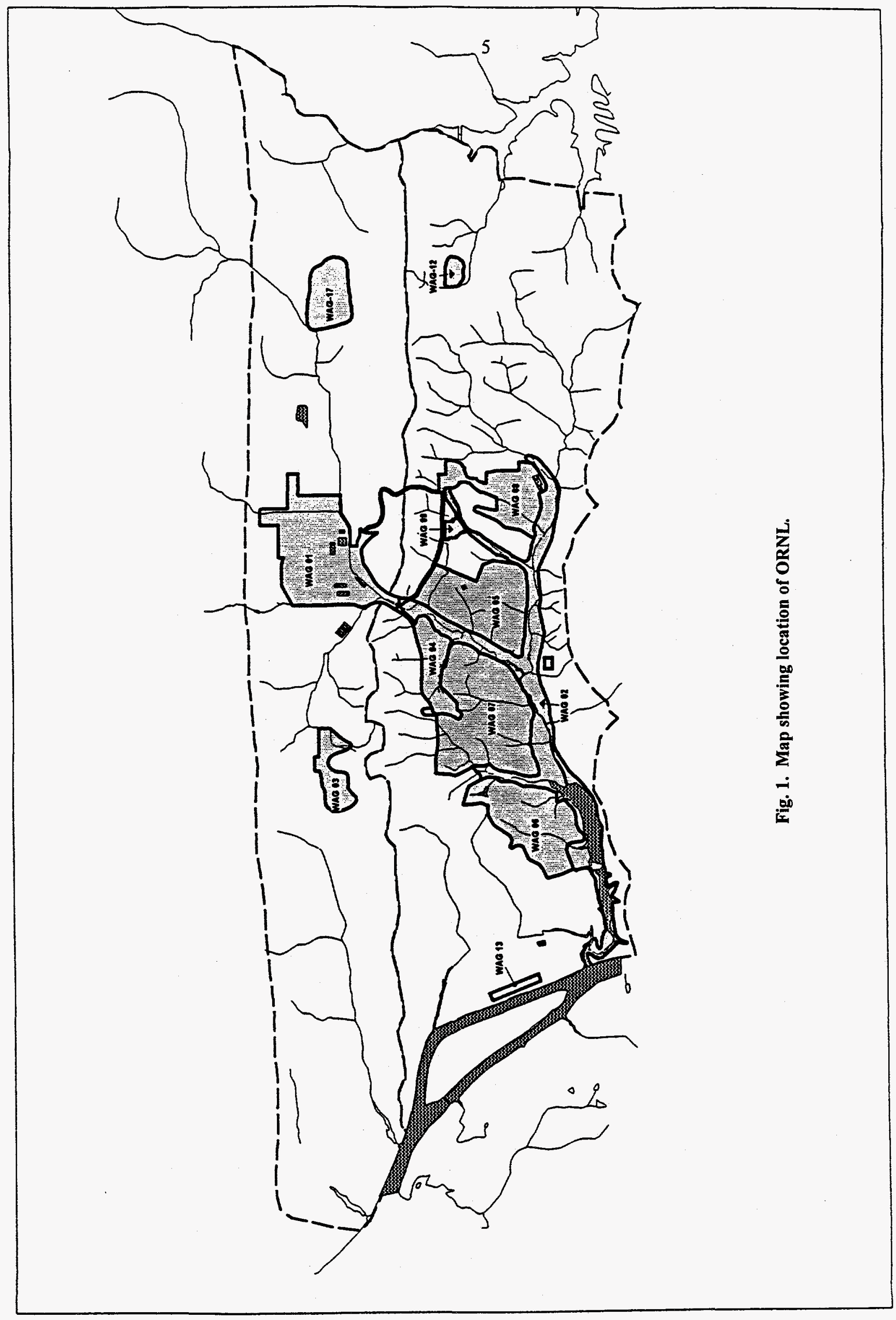




\section{FIELD ACTIVITIES}

\subsection{WELL DATA AND LOCATIONS}

There are many wells and piezometers within the ORNL site. Most of the wells and piezometers that will be monitored as part of the ORNL ER Area-Wide Groundwater Program efforts are in and around the many WAGs at the ORNL site. Specific locations and construction logs are not included in this WP. Locations and construction logs will be made available to field personnel by the ORNL ER Area-Wide Groundwater Program personnel.

\subsection{CONTINUOUS GROUNDWATER DATA COLLECTION}

The following sections delineate the equipment and the step-by-step technical instructions for pre-installation, installation, routine service, and removal of continuous groundwater monitoring equipment.

\subsubsection{Well Monitoring Equipment}

The following is a list of the equipment and supplies needed for the collection of continuous groundwater data in wells and piezometers. This list is provided as a reference, and some items may or may not be needed for each field activity. Additional items may be needed later.

- Electronic data loggers

- Pressure transducers

- Pressure transducer calibrator

- Conductivity probes w/cables

- Temperature probes w/cables

- $\quad \mathrm{pH}$ probes $\mathrm{w} /$ cables

- $\mathrm{pH}$, conductivity check solutions

- Thermometer

- Laptop personal computer (PC) electronic diskettes

- Data logger communications software

- Manual electronic water level indicator

- Field Logbook and Field Data Sheets

- Health and safety equipment (as required by applicable H\&SPs)

- Personnel protective equipment (as required by applicable H\&SPs)

- Radiation monitoring equipment

Personal thermoluminescent dosimeter (TLD)

- Chemical monitoring equipment (when required)

Hnu or equivalent

- Miscellaneous equipment

Kimwipes

Plastic waste bags

Hand soap or towelettes

Vinyl adhesive tape

Plastic sheeting

Insect repellant 
Sunscreen

Drinking water cooler

\subsubsection{Pre-Installation Instructions}

The following step-by-step instructions must be completed prior to installation of groundwater monitoring equipment. All field team members are familiar with the procedures, processes, and work instructions contained in this work plan. Proficiency with the procedures will be documented in the field log book and demonstrated in field surveillances. As a result, some of the following instructions can be implemented simultaneously by different field personnel.

1. Complete the initial information on an Installation Field Data Sheet (IFDS), Appendix A, for the well to be monitored. A separate form must be used for each well for paired wells. See the IFDS Instructions in Appendix A for a detailed description.

2. Don personal protective equipment (PPE) as required by the applicable H\&SP for the area in which the well is located. If the potential for drip water is suspected during the installation of monitoring equipment, place a plastic ground cover around the well.

3. Record on the IFDS any observed unusual or unexpected physical or environmental conditions relevant to well monitoring at this site. Make the required Health and Safety monitoring measurements as applicable (Hnu, Radiation, etc.).

4. Measure the well's static water level (SWL) from the well's measuring point as delineated below. SWL should be recorded in both elevation above mean sea level (MSL) and depth below measuring point (the top of the well casing unless otherwise noted).

A. Check the battery status of the electronic water level indicator (WLI). Battery checks should be performed at least once each day the WLI is used.

B. Locate the reference mark at the measuring point. The reference mark is typically the top of casing (TOC). If no mark is found, mark and use the highest point on the casing and document this on the IFDS.

C. Lower the probe into the well casing, preventing the probe cord ("tape") from scraping excessively against the TOC, until the probe's sensor indicates the presence of water.

D. Raise and lower the probe's sensor several times across the water's surface to ensure repeatability of the measurement.

E. Read and record water level as depth to water (DTW) from the measuring point to the nearest hundredths of a foot, including trailing zeroes (e.g. "24.10" rather than "24.1").

F. Remove the probe cord and probe from the well casing, preventing the cord from scraping the TOC.

5. Measure the total depth using a weighted tape. Lower the tape to the well bottom and determine the distance below the measurement point. Raise and lower the tape several 
times to locate a precise contact point. Record the measurement, calculate water column height, and complete the Pre-monitoring Section of the IFDS.

6. If the well is paired with an adjacent well, perform the pre-installation actions on the paired well as described in Steps 2 through 5 of this Section.

\subsubsection{Installation Instructions}

The following step-by-step instructions pertain to the installation of groundwater monitoring systems. All field team members are familiar with the procedures, processes, and work instructions contained in this work plan. Proficiency with the procedures will be documented in the field log book and demonstrated in field surveillances. As a result, some of the following instructions can be implemented simultaneously by different field personnel.

1. Install the transducer in the well or reducer pipe to the calculated depth, as calculated in the IFDS. If temperature, $\mathrm{pH}$, or specific conductivity is to be monitored, use check solutions and the thermometer to ensure that the probe is reading within acceptable uncertainty. If the probe reading is not within, acceptable uncertainty, recalibrate the probe to manufacture's specifications. Install the probe to a depth $1 / 2$ the operating range of the transducer or in the best professional judgement of the field technician if seasonal or well conditions warrant.

2. Program the data logger, using reference information to record water levels as true elevations (where TOC or other reference elevations are available). Set the test number and the number of inputs, and set the data type as Function, providing equations and/or parameters as appropriate. Set the File/Test ID (as per Section 3.4), parameters for each instrument (scale, linearity and offset), and sample interval. Typically sampling intervals of either 15 or thirty 30 minutes will be used. Program a start time on an even time increment (i.e. :00,:15,:30 or :45, as appropriate). Start the test to allow initiation of data collection. If any unusual logger behavior is noticed, conduct logger tests according to the manufacturer's instructions.

3. Perform a field transducer calibration check.

A. Measure and record SWL as in Step 4 of Section 3.2.2.

B. Raise the transducer a measured amount (about $25 \mathrm{~cm}$ ) and take a data logger reading. Compare the data logger reading to the SWL measurement by completing the Calibration Section of the IFDS, compensating for any change in SWL due to transducer movement.

C. If the physically measured transducer change differs from the change in data logger readings by greater than $5 \%$, then the transducer shall be recalibrated by the manufacturer or trained technician according to the manufacturer's instructions.

4. Remove all installation equipment and materials not required for system operation, including plastic ground cover and any disposable waste.

5. Record any additional data and comments and complete the IFDS. 
6. Decontaminate reusable equipment as per Section 6 of this WP and handle waste per the applicable waste management plan.

7. If required, secure the well and monitoring equipment (using locks, chains, sturdy containers, or some other security safeguard method).

\subsubsection{Routine Service Instructions}

The following step-by-step instructions pertain to the routine service groundwater monitoring systems. All field team members are familiar with the procedures, processes, and work instructions contained in this work plan. Proficiency with the procedures will be documented in the field log book and demonstrated in field surveillances. As a result, some of the following instructions can be implemented simultaneously by different field personnel.

1. Record information as appropriate on a Service Field Data Sheet (SFDS), Appendix A. Record on the SFDS any observed unusual or unexpected physical or environmental conditions relevant to well monitoring at this site.

2. Don PPE as required by the applicable H\&SP for the area in which the well is located. Check the data logger's system clock, setting the current date and time, if needed. Note on the IFDS if a correction of greater than five minutes is required.

3. Measure and record SWL as per Step 4 of Section 3.2.2.

4. Familiarity with electronic file transfer from a hard disk to a floppy disk is standard minimal professional practice, and additional training or procedures are not considered warranted.

5. Plot the data on the PC, using graphing software, and visually inspect for any irregularities. Irregularities include unexplained spikes, instantaneous offsets in water levels, or otherwise questionable data based on professional experience. Note in the Field Log Book and SFDS any areas of suspect data quality.

6. Perform a field water level transducer calibration check as per Step 3 of Section 3.2.3 and complete the calibration portion of the SFDS.

7. Record any additional data and comments and complete the SFDS.

8. Decontaminate reusable equipment as per Section 6 of this WP and handle waste as per the applicable Waste Management Plan.

9. If required, secure the well and monitoring equipment (using locks, chains, sturdy containers, or some other security safeguard method).

\subsubsection{Removal Instructions}

The following step-by-step instructions pertain to the removal of the groundwater monitoring systems. All field team members are familiar with the procedures, processes, and work instructions contained in this work plan. Proficiency with the procedures will be documented in the field log 
book and demonstrated in field surveillances. As a result, some of the following instructions can be implemented simultaneously by different field personnel.

1. Perform routine service of the monitored well(s) as specified in Steps 1 through 7 of Section 3.2.4. Record the required information on a Removal Field Data Sheet (RFDS), Appendix A.

2. Perform a field water level transducer calibration check as per Step 4 of Section 3.2.3. If required, perform calibration checks on the $\mathrm{pH}$, conductivity, and temperature probes as per the manufacturer's instructions. Complete the calibration portion of the RFDS.

3. Remove the transducer and/or the probes from the well.

4. Record any additional data and comments and complete the RFDS.

5. Decontaminate reusable equipment as per Section 6 of this WP and handle waste as per the applicable Waste Management Plan.

6. Secure the well and monitoring equipment (using locks, chains, sturdy containers, or some other security safeguard method).

\subsection{FIELD DOCUMENTATION INSTRUCTIONS}

Data collection will consist of recording information prior to, during, and upon completion of monitoring. All physically measured data will be recorded on preprinted field data sheets. All other field activities will be documented in the field log book. Data recorded on the data loggers will be transferred to a PC during routine service and upon completion of each monitoring period. Data will be transferred electronically in the field to properly labeled $3.5 "$ disks.

\subsubsection{Field Data Sheets}

Information contained in sentence of the paragraph.

Field Data Sheets will form the primary field documentation. Activities and physically measured data during installation, routine service, data checks, and well monitoring completion will be recorded on Field Data Sheets by the monitoring team. These sheets will be printed on water resistant paper, sequentially numbered, and secured in a three ring binder. These sheets will be photocopied daily, with the originals being secured in the subcontractor's project file and copies being carried with the field team. Examples of each field data sheet and the completion instructions are contained in Appendix A.

\subsubsection{Field Logbook}

All daily events will be documented using indelible waterproof black ink in a hard bound waterresistant dedicated logbook having sequentially numbered pages. This record will be dated, descriptive, and complete enough to allow chronological reconstruction of monitoring procedures. Dates and times will be recorded using the "mm/dd/yy" format and 24-hour ("military") time (e.g., 1500 for 3:00 p.m.). All corrections will be lined through with a single line, initialed, and dated 
adjacent to corrected text. The bottom of each page will be signed and dated by the person making the entries, and field log books will be independently reviewed and signed at the end of each day. Entries will include references to the unique identifiers for any Field Data Sheets used. All unused portions of pages will have a diagonal line drawn through them and this line will be initialed and dated by the person making the daily entries. Logbooks will be photocopied weekly, with copies stored in the subcontractor's project file.

\subsection{DATA LOGGER OPERATION AND FILE NAMING INSTRUCTIONS}

Operation of the data logger and attached instruments will be verified upon installation, after one week, on the third week, and monthly thereafter until the monitoring period is completed. The monitoring period is at the discretion of the ORNL ER Area-Wide Groundwater Program Project Manager. Data displays using PC graphing software, self-check routines within the data logger, and measurement changes on the data logger display will be indicative of satisfactory operation. Manufacturer's operating procedures will be provided to the field teams for programming, operation, and verification of the data loggers and attached probes.

For well monitoring, data logger file names will be identified with a unique code compatible with the type of data logger being used. For some data loggers, the unique code is restricted to a five-digit numerical code. For others, the unique code can be an eight-digit alphanumeric code. These are relevant to the types of loggers that will be used initially for this efforts. Logger types and file naming conventions may change during the duration of these efforts. Regardless of the logger file naming convention, files will be assigned a unique identifier and will be recorded on the Field Data Sheets. 


\section{PROJECT ORGANIZATION}

\subsection{PROJECT PARTICIPANTS}

Continuous monitoring of groundwater data under the ORNL ER Area-Wide Groundwater Program is funded through the ORNL ER Program, with management and operations for the project directed through the ORNL ER Division. Key personnel, their affiliations, and phone numbers are listed in Table 1. An organizational chart for the efforts described by this WP is presented in Fig 2.

Table 1. Key project personnel

\begin{tabular}{llc}
\hline \multicolumn{1}{c}{ Responsibility } & Name & Telephone \\
\hline DOE Program Manager & Gary Bodenstein & $576-9429$ \\
DOE Quality Assurance Specialist (QAS) & Ivette Mentalvo & $\mathbf{2 4 1 - 4 3 3 8}$ \\
ORNL ER Program Director & Harry Boston & $576-0311$ \\
ORNL ER Area-Wide Groundwater Program Manager & Dick Ketelle & $574-5762$ \\
ORNL ER QAS & Pete Schrandt & $576-9926$ \\
ORNL Lab Shift Superintendent (LSS)* & & $574-6606$ \\
Subcontractor Project Manager & & \\
Subcontractor Field Team Leader
\end{tabular}

*No individual has been designated because this office operates 24 hours a day with rotating superintendents.

${ }^{\dagger}$ Individuals have not been designated since the subcontractor or subcontractor personnel may be subject to change over the duration of this plan. 


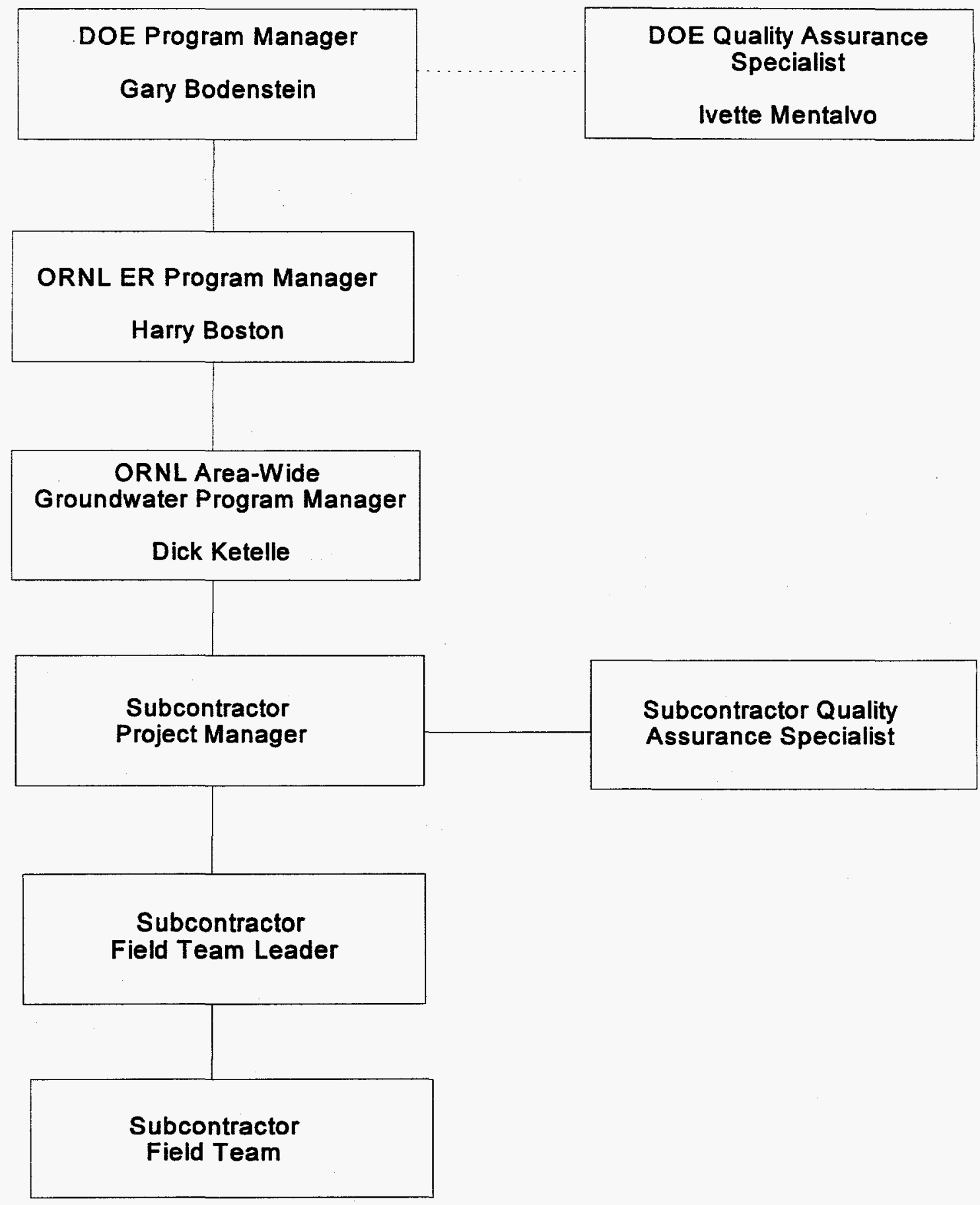

Fig. 2. Organizational structure of the ORNL Area-Wide monitoring efforts. 


\subsection{PROJECT PERSONNEL RESPONSIBILITIES}

This project is being conducted under the direction of the ORNL ER Program. Project responsibilities defined here apply only to the collection, verification, and dissemination of data collected as part of this project. Control of project activities affecting quality and/or safety will be implemented throughout the duration of the project to the degree necessary to ensure that all quality and safety objectives are met. All project personnel are responsible for quality assurance/quality control and safety procedures and processes during implementation of this plan. The roles and responsibilities of project personnel specific to Quality Assurance (QA) are described in the QAPjP. The roles and responsibilities of project personnel specific to health and safety are presented in the applicable H\&SP(s). The roles and responsibilities delineated below do not supersede those defined in the QAPjP or applicable H\&SP(s).

\subsubsection{ORNL ER Area-Wide Groundwater Program Manager}

The ORNL ER Area-Wide Groundwater Program Manager reports progress and results to the ORNL ER Program Manager and the Department of Energy (DOE) Program Manager. The ORNL ER Area-Wide Groundwater Program Manager is responsible for ensuring that the planned activities meet the ORNL ER Area-Wide Groundwater Program requirements. The ORNL ER Area-Wide Groundwater Program Manager will also conduct periodic technical review of the data acquired during this project to ensure that it meets the requirements of the ORNL ER Area-Wide Groundwater Program. The Groundwater Program Manager is responsible for ensuring that the subcontractor has all applicable passes and permits, and has completed all notifications prior to initiating field activities. The Groundwater Program Manager shall ensure that the Subcontractor Project Manager, Field Team Leader, and Field Team members have sufficient technical direction in the determining the schedule and order in which wells will be monitored. The Groundwater Program Manager will also be responsible for keeping the Field Team apprised of any changes in the status of wells or monitoring schedules. Other responsibilities of the Groundwater Program Manager are delineated below.

- Consulting with the ORNL ER QAS on quality-related matters.

- Consulting with the appropriate health and safety entity on health- and safety-related matters.

- Consulting with the appropriate technical personnel regarding technical issues.

- Delineation of ORNL ER Area-Wide Groundwater Program Objectives and requirements.

- Incorporating the appropriate QA, health and safety, and technical requirements for the ORNL ER Area-Wide Groundwater Program in these monitoring activities.

- Investigating quality, health and safety, and/or technical problems encountered during groundwater monitoring operations, determining their root cause, proposing solutions, implementing corrective actions, and obtaining the concurrence from ORNL personnel on the appropriateness of the corrective action. 
- Initiating stop-work actions when conditions or procedures adverse to quality or safety warrants immediate action.

- Communicating data collected from these efforts to the appropriate data users and decision makers.

- Responsible for management assessment.

\subsubsection{ORNL ER QAS}

The ORNL ER QAS is responsible for ensuring that appropriate planning documents as related to quality are in place and verified in accordance with applicable requirements. The ORNL ER QAS is responsible for reporting to the ORNL ER Area-Wide Groundwater Program Manager any instances of quality related matters that are inconsistent with the collection of continuous groundwater data objectives and is responsible for independent assessments of work performance.

\subsubsection{Subcontractor Project Manager}

The Subcontractor Project Manager is responsible for overall project execution. The Subcontractor Project Manager will report to the ORNL ER Area-Wide Groundwater Program and Groundwater Project managers. The responsibilities of the Subcontractor Project Manager include:

- coordinating with ORNL ER personnel, including the Groundwater Program and Project Managers;

- maintaining auditable project documentation of all required records;

- communicating results of the monitoring efforts to the ORNL ER Area-Wide Groundwater Project Manager;

- validating and transmitting field data to the ORNL ER Area-Wide Groundwater Project Manager;

- ensuring that field personnel adhere to all procedures, processes, work instructions, and protocol for the collection of continuous groundwater monitoring data; and

- initiating stop-work orders when project quality and/or safety may be jeopardized for any reason.

\subsubsection{Subcontractor Field Team Leader}

The Field Team Leader will oversee the field activities associated with this project and will be responsible for site accessibility, QA, and will delegate further responsibilities to other members of the Field Team. The Field Team Leader will report to the Subcontractor Project Manager and will have the following responsibilities:

- ensuring that the groundwater monitoring and decontamination procedures, processes, work instructions, and protocol are effectively implemented; 
- interfacing with the assigned ORNL Health Physics (HP), Industrial Hygiene (IH), and other safety-related personnel; and

- initiating stop-work actions when conditions or procedures adverse to quality or safety warrants immediate action.

\subsubsection{Subcontractor Field Team Members}

The Subcontractor Field Team members are responsible for:

- ensuring all QA, health and safety, and technical requirements for groundwater monitoring operations and decontamination are adhered to;

- interfacing with the Field Team Leader on all quality-related matters; and

- initiating stop-work actions when conditions or procedures adverse to quality or worker safety warrants immediate action.

\subsubsection{Subcontractor QAS}

The Subcontractor QAS is responsible for maintaining the subcontractor's internal Quality Program. The Subcontractor QAS reports to the principle-in-charge of the subcontracting firm. The responsibilities of the Subcontractor QAS include:

- $\quad$ administering the Subcontractor QA Program;

- conducting quality-related audits and surveillance of subcontractor activities and fields at the request of the Subcontractor Project Manager; and

- initiating stop-work actions when conditions or procedures adverse to project quality or safety warrants immediate action. 


\section{MOBILIZATION PLAN}

Mobilization will be necessary prior to initiating field operations. This section addresses predeployment activities such as training the field team members, obtaining the necessary permits and passes, addressing security issues, and notifying appropriate ORNL site departments.

\subsection{GENERAL TRAINING REQUIREMENTS}

The General Training Requirements delineated in this section are primarily related to personnel safety. These training requirements are general in nature and represent the minimum training necessary to perform the activities addressed by this plan. Additional training may be required as delineated in the applicable H\&SP. The General Training Requirements are:

- Energy Systems General Employee Training (GET);

- General Hazard Communication Training;

- $\quad$ ORNL Site-Specific Training (occurs during badging);

- 40-hour Hazardous Waste Operations and Emergency Response (HAZWOPER) Training;

- 8-hour Refresher Training (as required);

- $\quad$ Radiation Worker Training II; and

- Non-paved Surface Drivers Training.

\subsection{TASK-SPECIFIC TRAINING REQUIREMENTS}

Task-specific training pertain to the specific tasks being conducted. These task-specific training requirements are primarily concerned with technical and quality related issues. Task-specific training requirements for this project shall include:

- Field Data Sheet/field logbook entry and maintenance;

- data logger programming and equipment-setup;

- routine maintenance/cleaning of instruments and sensors;

- data management protocol; and

- decontamination procedures.

The above task-specific training will be conducted and documented in the field logbook prior to initiation of field activities.

\subsection{DOSIMETRY PROGRAM}

All groundwater monitoring and supervisory personnel and visitors entering the ORNL site are required to participate in the external dosimetry program. TLDs are used to measure personal radiation doses and are issued and monitored on a quarterly basis by ORNL HP. Further radiological monitoring requirements are presented in the applicable H\&SP. All project personnel must possess a current TLD prior to the initiation of work. 
Internal dosimetry will be maintained on the schedule required by the most restrictive applicable H\&SP.

\subsection{PERMITS AND PASSES}

To conduct the groundwater monitoring operations at ORNL, a number of permits and passes must be obtained and maintained. The ORNL ER Area-Wide Groundwater Project Manager will be responsible for ensuring that all applicable permits are obtained prior to initiation of field activities.

The following subsections describe the permits and passes required for work at ORNL. Included with each item is the information required to obtain the permit, scheduling requirements, and, if known, the ORNL contact.

\subsubsection{Vehicle Passes}

A vehicle will be used to perform the groundwater monitoring field operations. Vehicle(s) access may not be required to access all wells. If vehicle passes are required, they will issued by the ORNL Security Department at the request of the ORNL ER Area-Wide Groundwater Project Manager.

If vehicles are to be parked on the site overnight, the ORNL Security Department will need to be notified of the approximate location where subcontractor vehicles will be parked.

All subcontractor vehicles must be in good condition, suitable to pass the appropriate inspections. Each vehicle must have subcontractor signs on the doors. Inspections of subcontractor vehicles may be performed prior to moving it on-site, during operations, and before departure from ORNL.

\subsubsection{Radiation Work Permits}

Radiation Work Permits may be required before access to radiological areas to ensure that the proper precautions (i.e,. PPE, radiation monitoring, etc.) are taken, to maintain worker safety, and to reduce the potential spread of radiological contamination. In the event that personnel must access a radiological area, Field Team Members shall contact the appropriate Site Health and Safety Officer (SHSO) for the site(s) being monitored. The SHSO will determine if a radiation work permit already exist for the site being monitored. If a Radiation Work Permit does not exist and one is required, the SHSO will support field team members in preparing a permit.

\subsection{SECURITY ISSUES}

Field team members will require uncleared access badges prior to working at ORNL. Currently there are not any wells in areas requiring security clearances. 


\subsection{NOTIFICATION REQUIREMENTS}

\subsubsection{ORNL Lab Shift Superintendent}

The ORNL LSS requires notification of ongoing field activities. The LSS will need to know of the monitoring activities, the duration of activities and the personnel involved.

\subsubsection{Health and Safety Oversight}

Where the site-specific H\&SP requires HP or IH oversight to access wells, the ORNL ER AreaWide Groundwater Program Manager will arrange for coverage. Since advance notification requirements are subject to change, the proper time period for notification will be determined by the ER Area-Wide Groundwater Program Manager and communicated to the Subcontractor Project Manager. 


\section{DECONTAMINATION}

All reusable field equipment that comes into direct or incidental contact with well water will be decontaminated between wells before reuse to prevent cross-contamination of wells.

\subsection{PERSONNEL DECONTAMINATION}

Should radioactive contamination be detected on an individual, the SHSO or the individual contaminated will contact HP immediately.

\subsection{EQUIPMENT DECONTAMINATION}

All reusable field equipment that comes into direct or incidental contact with well water will be decontaminated between wells before reuse to prevent cross-contamination of wells. If the area being monitored requires that decontamination be performed at a specific decontamination station/facility, then the potentially contaminated equipment will be transported by vehicle, if necessary, to that station for decontamination. All potentially contaminated equipment will be wrapped in plastic sheeting to mitigate the spread of decontamination during transportation. Decontamination operations for each well will be recorded in the logbook.

\subsection{DECONTAMINATION INSTRUCTIONS}

The following instructions will be used to decontaminate all reusable equipment, with the exception of electronic water level indicators:

- Liquinox wash;

- tap water rinse;

- deionized water rinse; and

- $\quad$ either air drying or drying with disposable wipes.

Once decontaminated, the equipment will be wrapped in plastic or aluminum foil and stored in a secure location.

Electronic water level indicators will be decontaminated using the following instructions.

1. Tap water rinse the water level indicator tape and probe that comes into contact with well water.

2. Wipe dry with wipes.

3. If particulate matter (i.e., mud, sludge, algae, etc.) is still visible on the probe and tape, rinse and wipe dry again.

4. If the second rinse and wipe does not remove all visible particulates, then conduct a complete decontamination as for other reusable equipment. 


\subsection{DECONTAMINATION EQUIPMENT}

Decontamination personnel will need the appropriate safety equipment and technical expertise for performance of the washing and rinsing procedures. All generated wastes will be handled in accordance with the appropriate waste management practices/plan for the area being monitored.

The equipment required for decontamination is listed in Table 2.

Table 2. Decontamination equipment

\begin{tabular}{lll}
\hline Disposable wipes & $\begin{array}{l}\text { Hand sprayers with Teflon® tip } \\
\text { nozzles }\end{array}$ & Disposable latex gloves \\
Liquinox & Heavy duty plastic sheeting & Drum funnel(s) \\
Deionized water & Tap water & Plastic tub(s) \\
Plastic wrap & Plastic brushes & Spill response kit \\
Bucket(s) & Face shield(s) & \\
Aluminum Foil & Tape & \\
\hline
\end{tabular}



Appendix A

Field Data Sheets and Instructions 


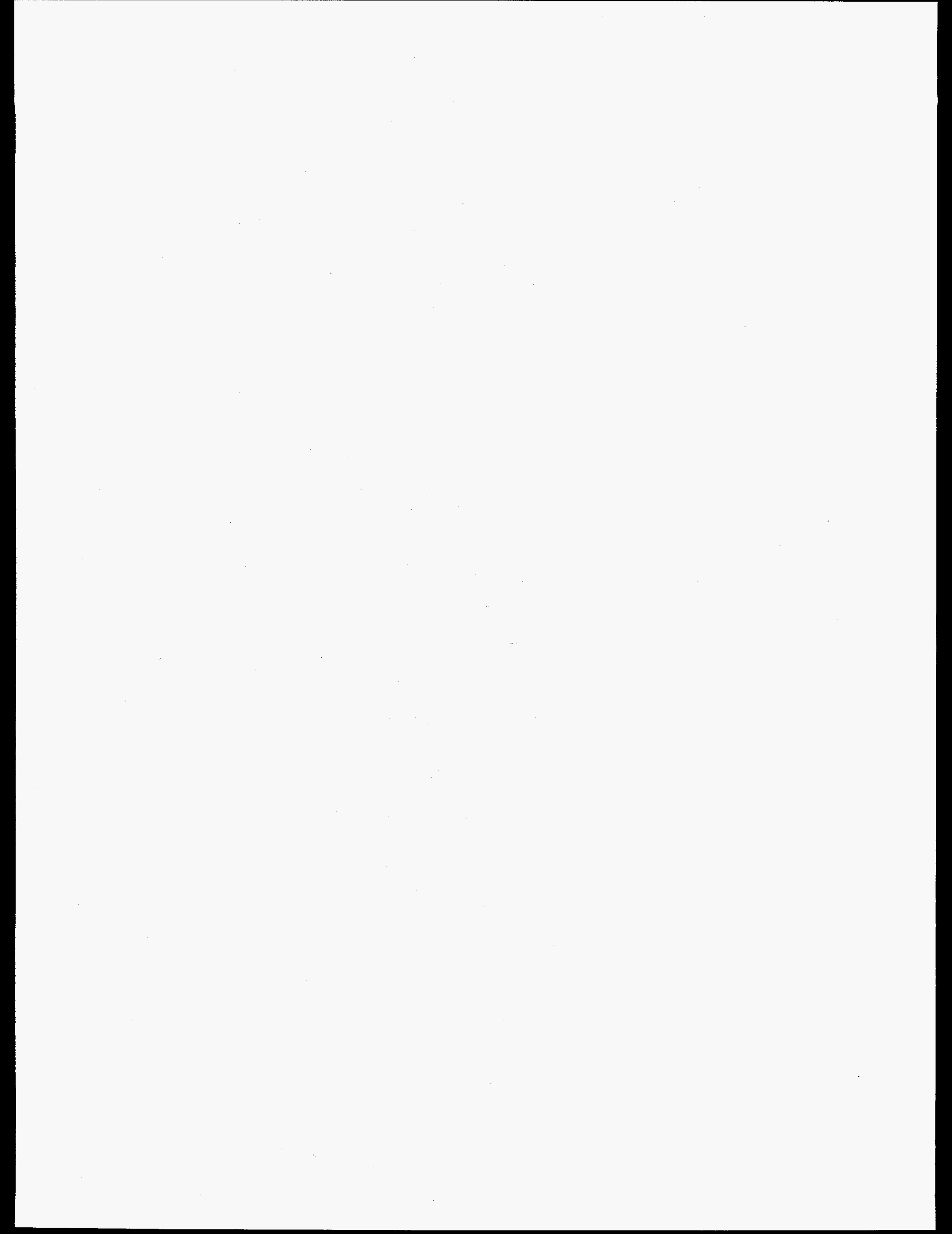




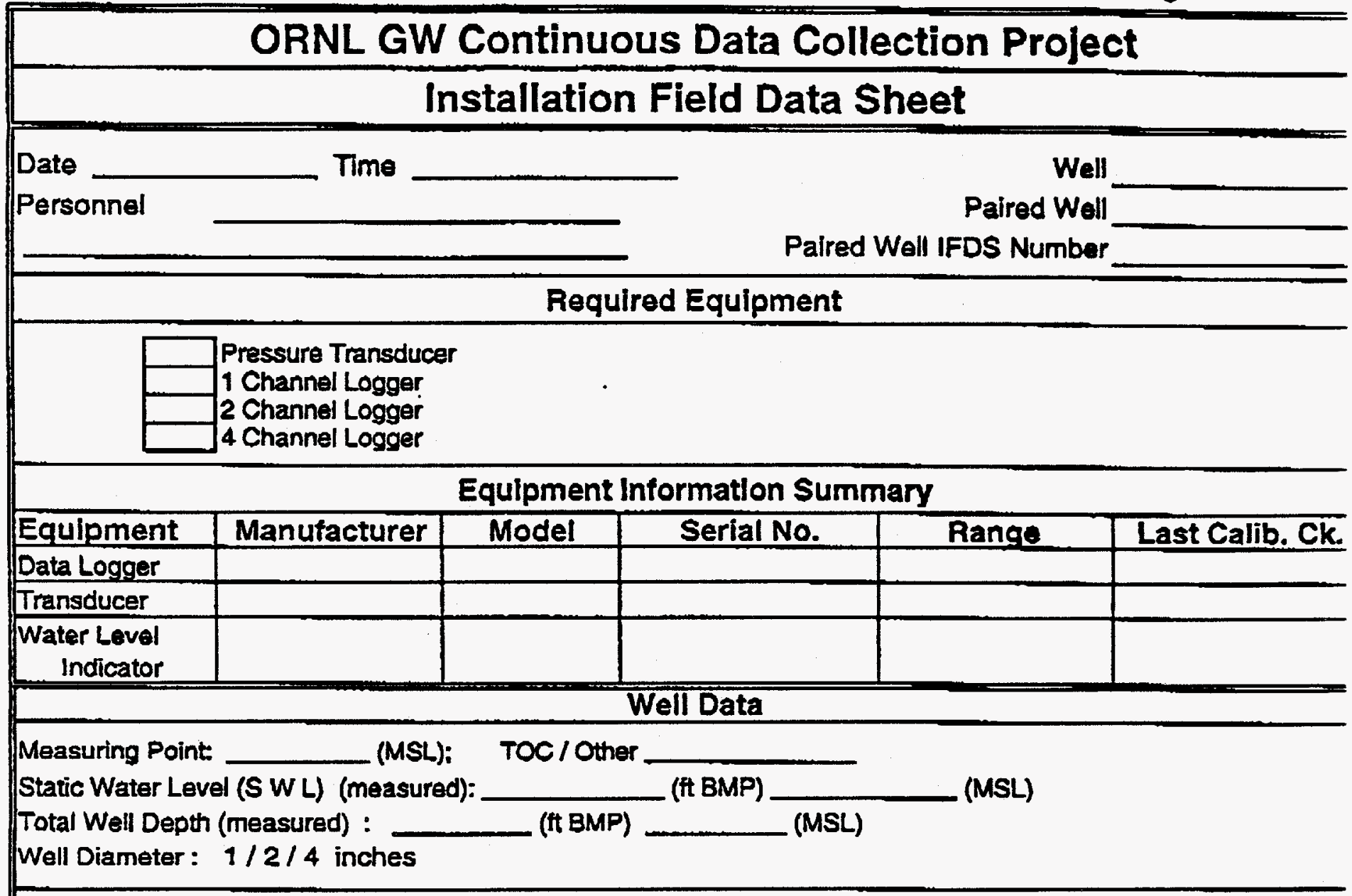

\section{Comments}

\begin{tabular}{|c|c|c|c|}
\hline \multicolumn{4}{|c|}{ Calculations } \\
\hline & Ft BMP & - & Ft BMP \\
\hline $\begin{array}{l}\text { Total Well } \\
\text { Depth }\end{array}$ & & $\begin{array}{l}\text { SWL } \\
\text { (measured) }\end{array}$ & \\
\hline Less SWL & & $\begin{array}{l}\text { Plus Transducer } \\
\text { Required Depth }\end{array}$ & \\
\hline $\begin{array}{l}\text { Water Column } \\
\text { Height }\end{array}$ & & $\begin{array}{l}\text { Depth of } \\
\text { Transducer }\end{array}$ & \\
\hline
\end{tabular}

\begin{tabular}{||l|l|l|l}
\hline Data Recorded by & Date & Data Verified by & Date \\
\hline & & & \\
\hline
\end{tabular}




\section{ORNL GW Continuous Data Collection}

\section{Installation Field Data Sheet}

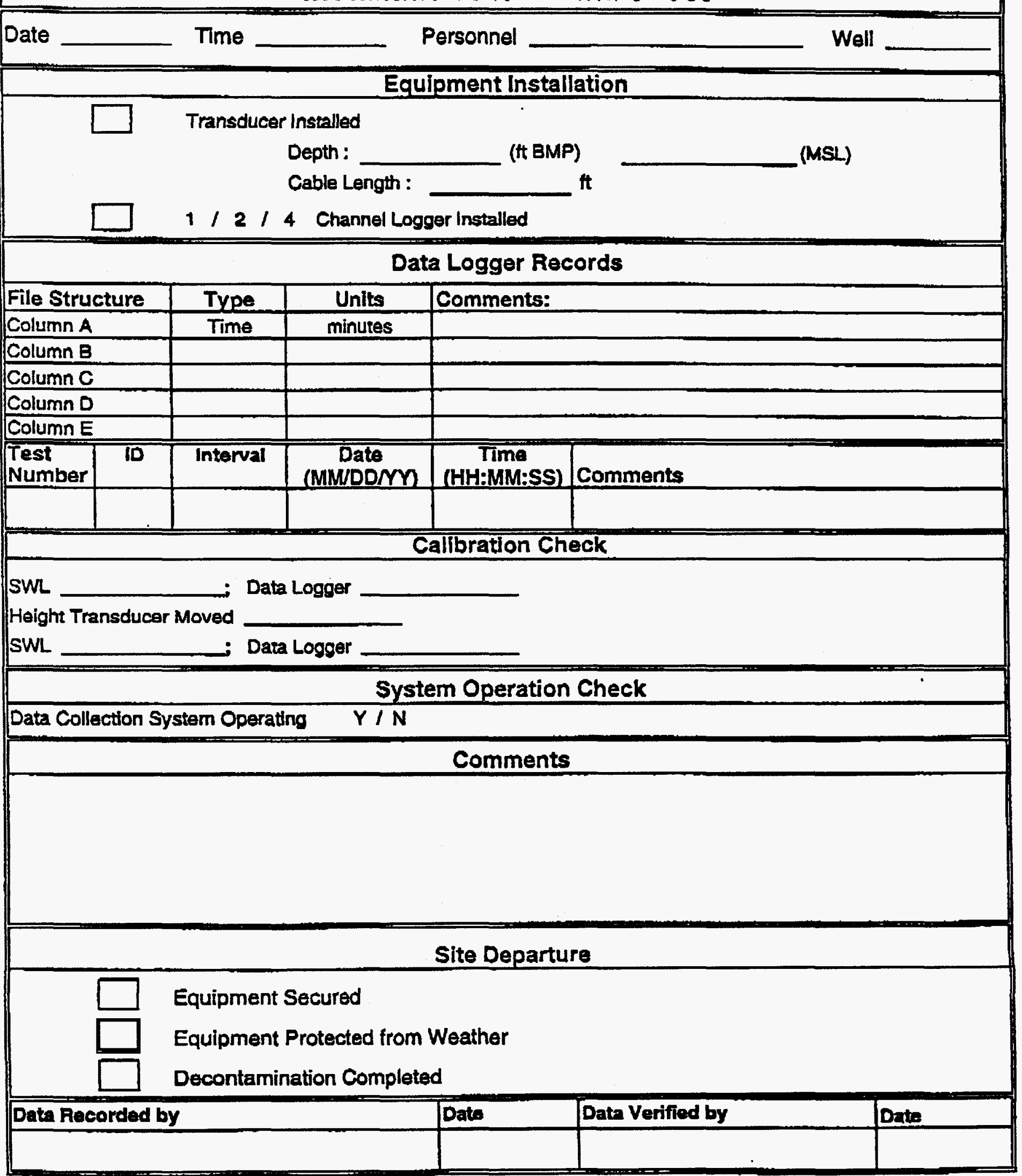




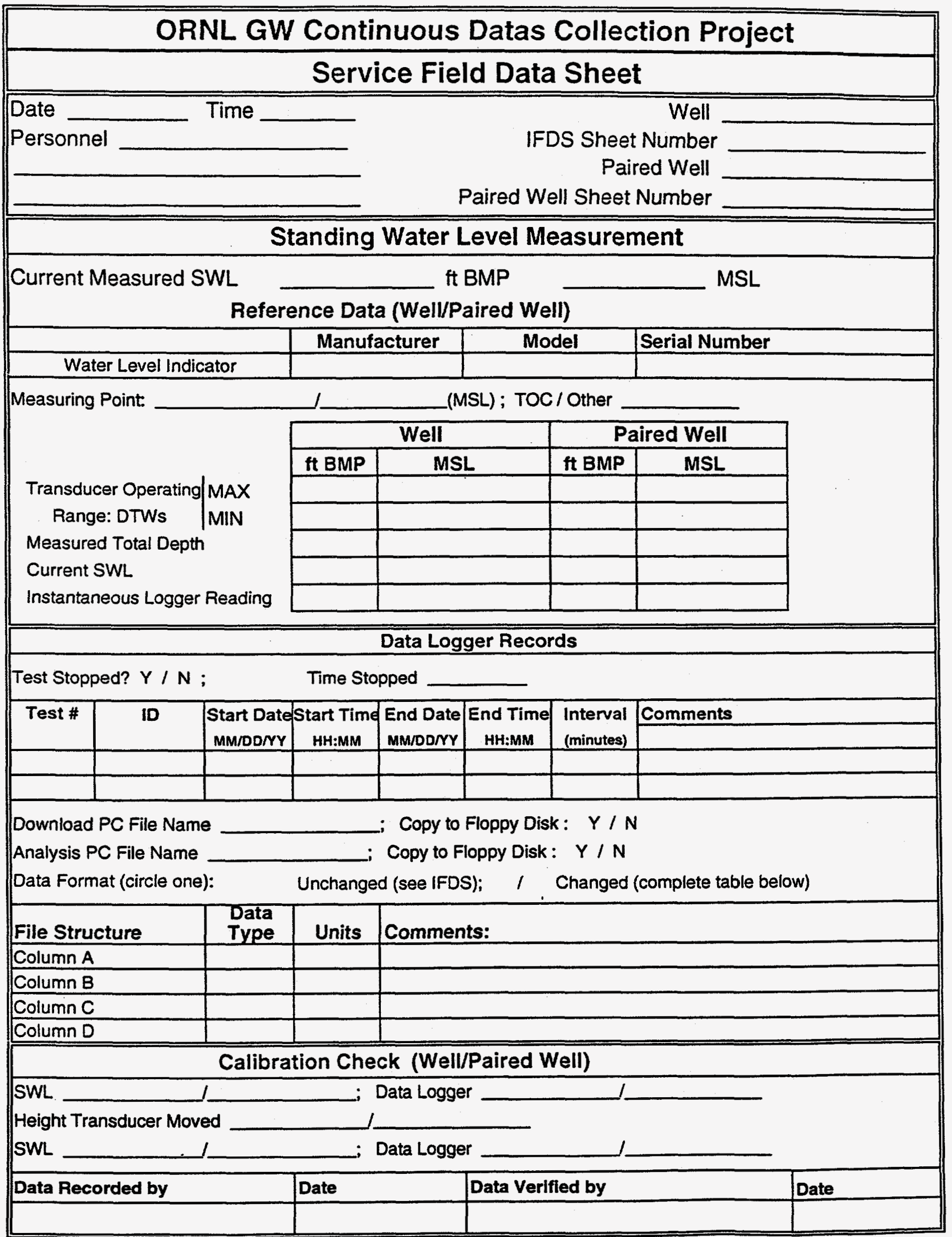


Sheet Number:

\section{ORNL GW Continuous Data Collection}

\section{Removal Field Data Sheet}

\begin{tabular}{||lcr|}
\hline $\begin{array}{l}\text { Date } \_ \\
\text {Personnel }\end{array}$ & \multicolumn{1}{c}{ Well } \\
\hline \hline
\end{tabular}

\section{Equipment Removal and Site Departure}

Equipment and material removed from site?

Cap replaced on Well? On Paired Well?

Wellhead locked on Well? On Paired Well?

Site cleaned up?

HP survey required?

HP survey completed?

Decontamination completed?
$\mathrm{Y} / \mathrm{N}$

$Y / N \quad Y / N$

$Y / N$

$Y / N$

$Y / N$

$Y / N$

$\mathrm{Y} / \mathrm{N}$

$Y / N$

\begin{tabular}{|l|l|l|l|}
\hline Data Recorded by & Date & Data Verified by & Date \\
\hline & & & \\
\hline
\end{tabular}




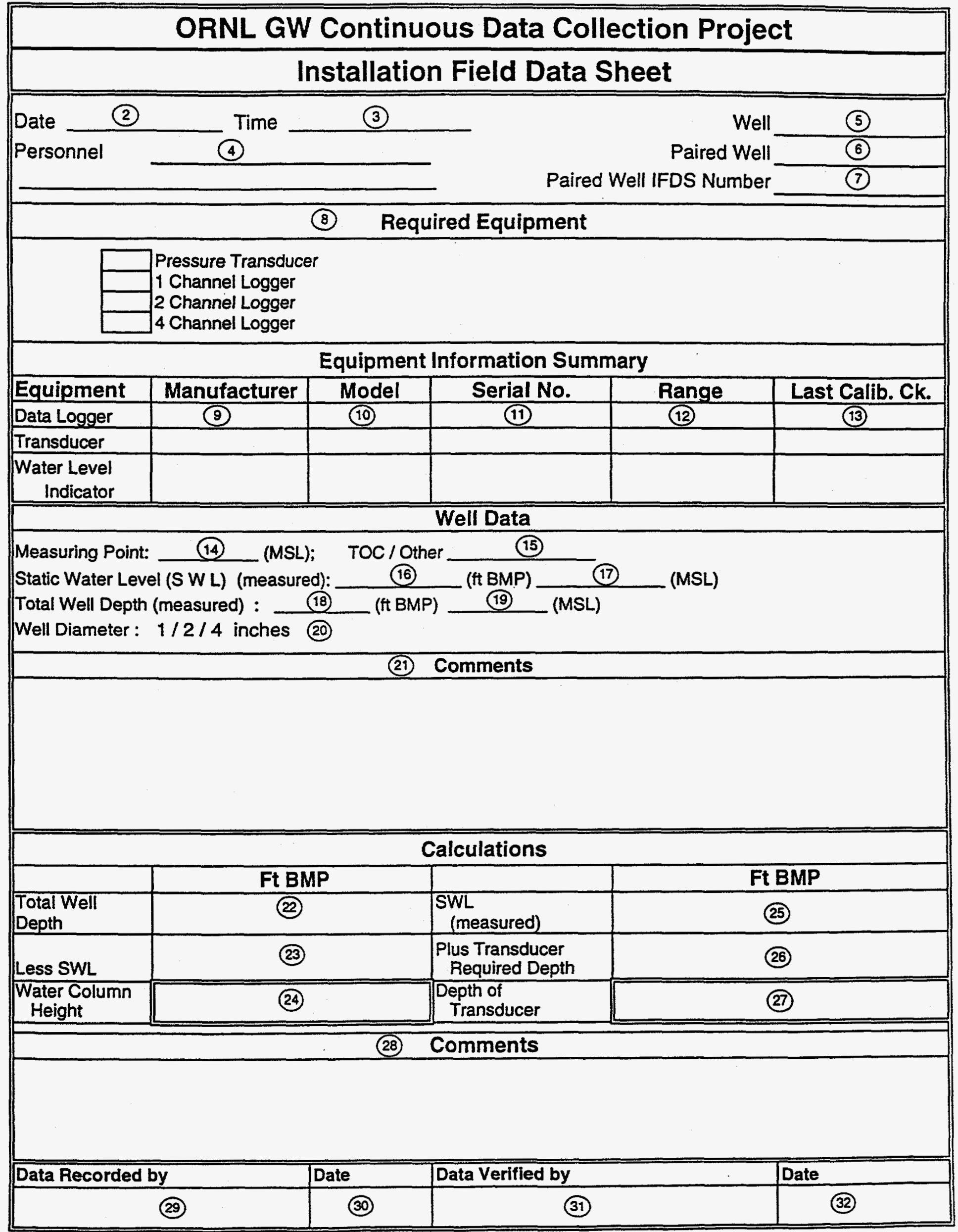




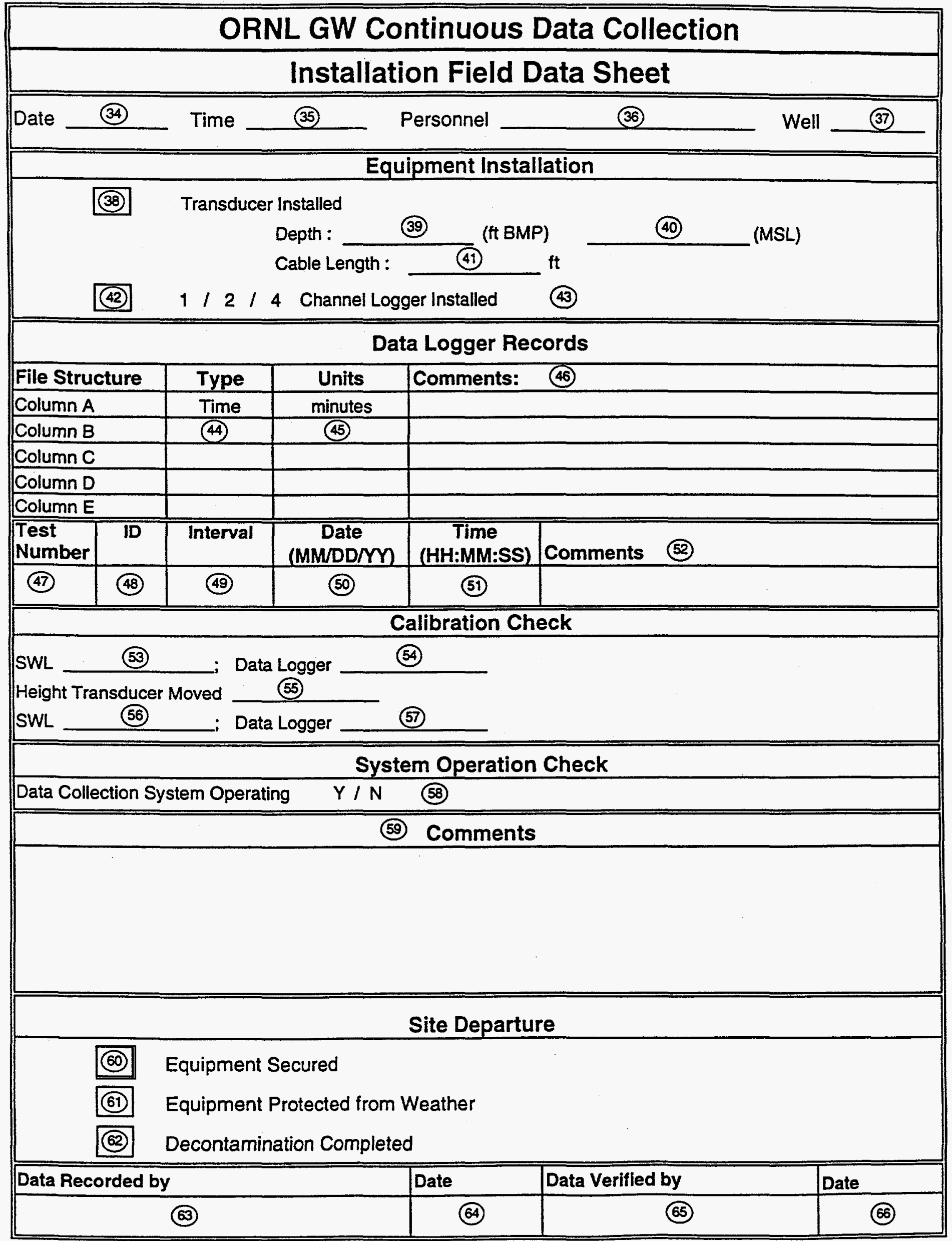


Sheet Number:

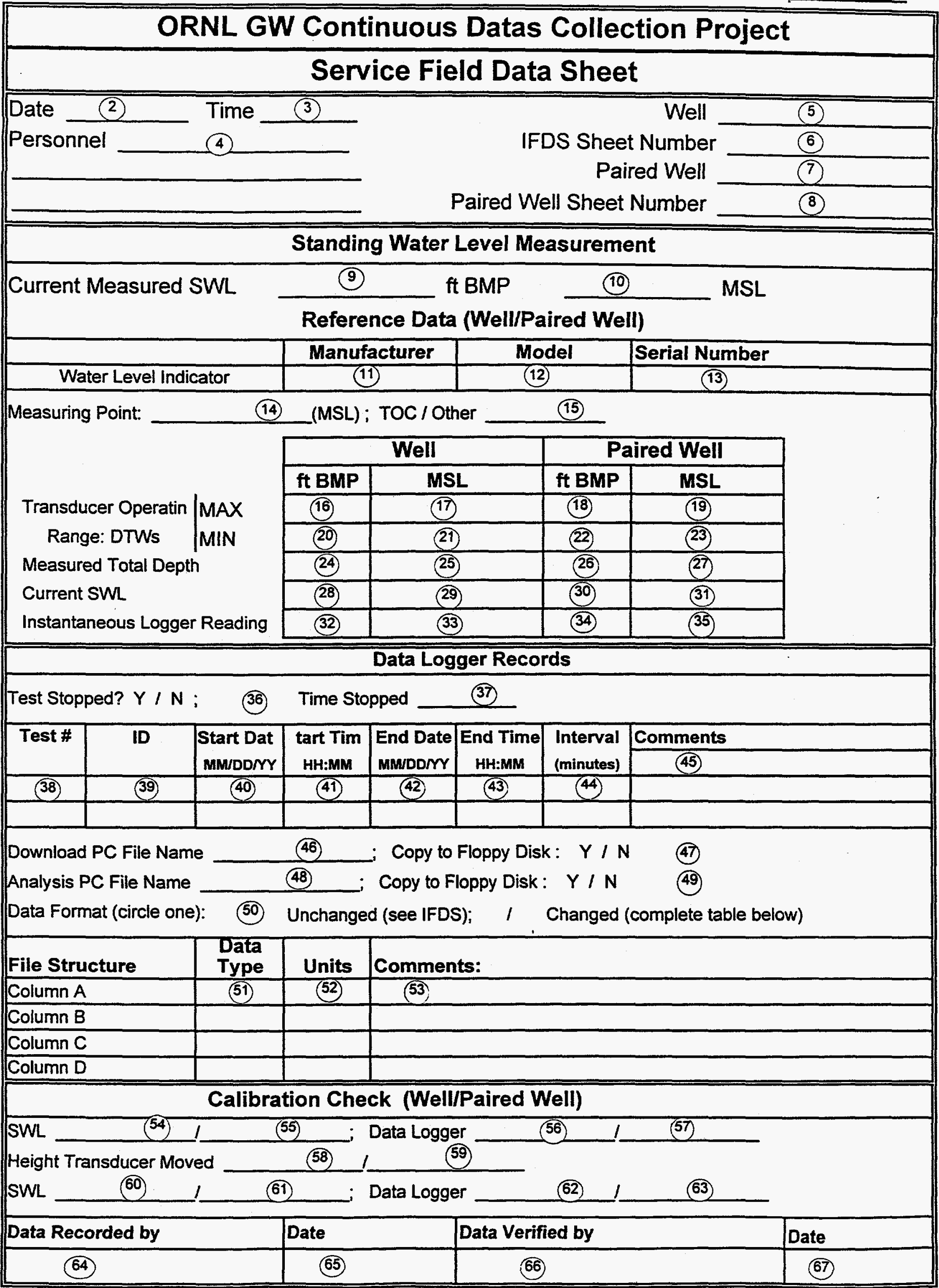




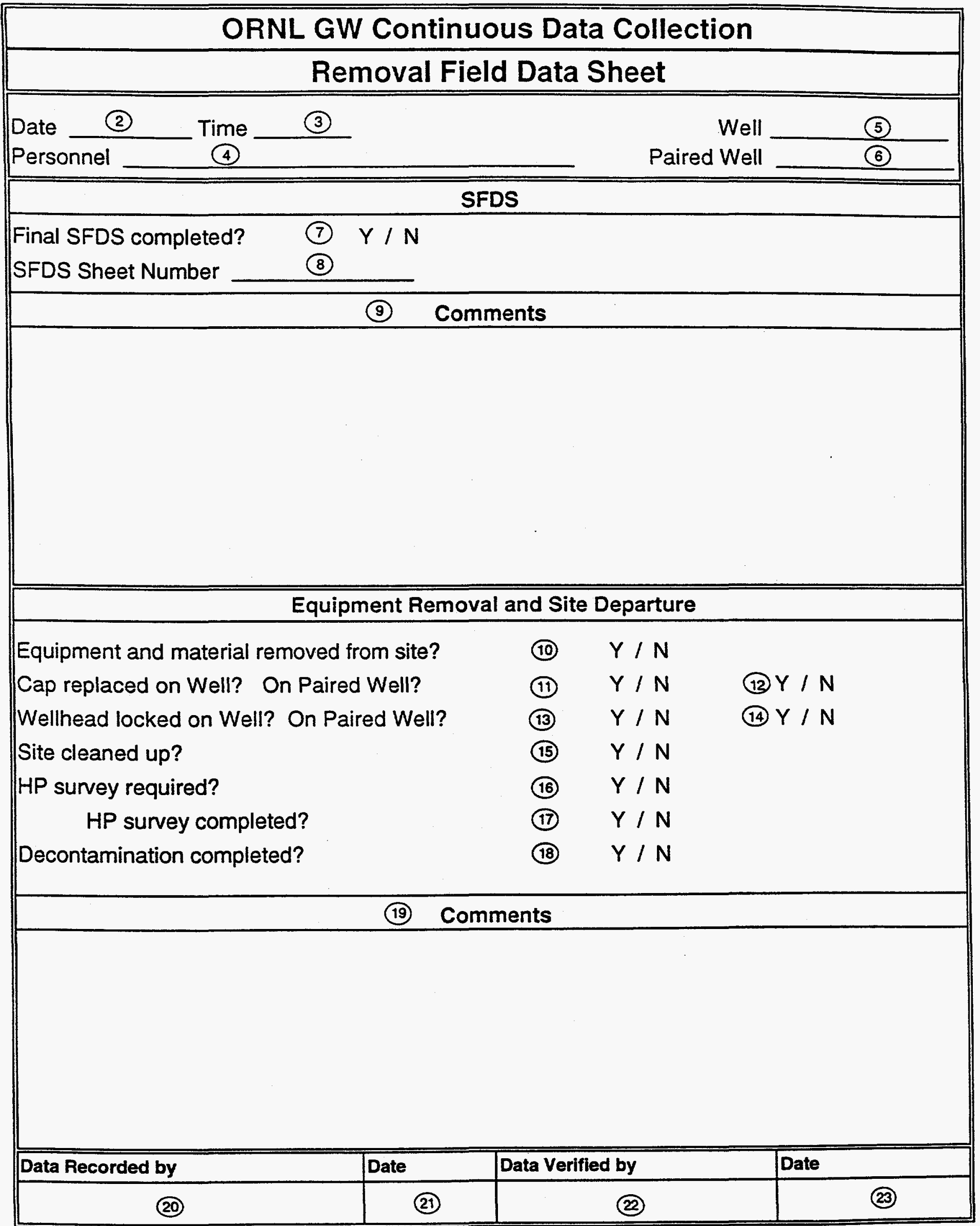




\section{A-2.1 INSTALLATION FIELD DATA SHEET (IFDS)}

\section{A-2.1.1 PAGE 1 - HEADING INFORMATION}

1) Enter the sheet sequential number (e.g., 001).

2) Enter the date of the installation, in the format MM/DD/YY (e.g., 01/31/95).

3) Enter the time that this page was started, in 24-h format (HH:MM) (e.g., 12:01).

4) Enter the name(s) of the person(s) performing the installation.

5) Enter the well ID (e.g., UNW-001).

6) Enter the well ID as per (5) for any well paired with the designated well on this IFDS.

7) Enter the paired well's IFDS sheet number.

\section{A-2.1.2 REQUIRED EQUIPMENT}

8) Check the boxes in this section that corresponds to the equipment to be installed.

\section{A-2.1.3 EQUIPMENT INFORMATION SUMMARY}

9) Enter the manufacturer of the equipment to be installed.

10) Enter the manufacturer's model number.

11) Enter the manufacturer's serial number.

12) Enter the manufacturer's stated range or rating for the equipment to be installed (e.g., 10 psi for the transducer).

13) Enter the last date the equipment was either calibrated or had the calibration checked, whichever was the most recent.

\section{A-2.1.4 WELL DATA}

14) Enter the measuring point elevation above MSL in feet.

15) Circle the measuring point used. If other, state in the blank provided.

16) Measure and record the SWL in $\mathrm{ft}$ BMP.

17) Calculate and record SWL above MSL.

18) Measure and record total well depth in $\mathrm{ft}$ BMP.

19) Calculate and record total well depth above MSL. 
20) Circle the well casing diameter.

21) Enter comments regarding the well data, notes of explanation, or any discrepancies encountered.

\section{A-2.1.5 CALCULATIONS}

22) Enter total well depth from (18).

23) Enter SWL from (16).

24) Calculate water column height by subtracting (23) from (22).

25) Enter SWL from (16).

26) Enter the depth for proper transducer operation.

27) Calculate the $\mathrm{ft}$ BMP for the transducer by adding (25) to (26).

28) Enter comments regarding the calculations, notes of explanation, or any discrepancies encountered.

\section{A-2.1.6 PAGE 1 - FOOTER INFORMATION}

29) The signature of the person who entered the data on this sheet.

30) Date the information on this sheet was entered.

31) The signature of the Project Manager or their designee after the sheet has been checked for completeness, accuracy and technical content.

32) The date (31) was completed.

\section{A-2.1.7 PAGE 2 - HEADING INFORMATION}

33) Enter the sheet sequential number as entered on page 1 in (1).

34) Enter the date of the installation, in the format MM/DD/YY (e.g., 01/31/95).

35) Enter the time that this page was started, in 24-h format (HH:MM) (e.g., 12:01).

36) Enter the initial(s) of the person(s) performing the installation.

37) Enter the well ID (e.g., UNW-001) as entered on page 1 in (5). 


\section{A-2.1.8 EQUIPMENT INSTALLATION}

38) Check this box once the transducer is installed.

39) Enter the depth at which the transducer is installed.

40) Compute and record the transducer installation depth above MSL.

41) Enter the cable length as stated on the manufacturer's identification tag attached to the cable.

42) Check this box once the data logger is installed.

43) Circle the number corresponding to the number of data channels the data logger can record.

\section{A-2.1.9 DATA LOGGER RECORDS}

44) Enter the type of data to be recorded in the column of the file structure (e.g., elevation).

45) Enter the units for the data type in (44) (e.g., feet).

46) Enter comments regarding the data logger records, notes of explanation, or any discrepancies encountered.

47) Enter the test number as displayed on the logger. If the logger is a one channel logger, no test number will be displayed, therefore, enter NA.

48) Enter the file identification number.

49) Enter the test interval in minutes.

50) Enter the test start date in $M M / D D / Y Y$ format.

51) Enter the test start time in 24-h format (HH:MM:SS).

52) Enter comments regarding the data logger records, notes of explanation, or any discrepancies encountered.

\section{A-2.1.10 CALIBRATION CHECK}

53) Measure and record the SWL in $\mathrm{ft} B M P$.

54) Take and record a data logger reading

55) Raise the transducer a specific height [e.g., one (1) foot] and record in feet.

56) Repeat (53).

57) Repeat (54). 


\section{A-2.1.11 SYSTEM OPERATION CHECK}

58) Check the data logger and circle $\mathrm{Y}$ (yes) if the data logger is collecting data or $\mathrm{N}$ (no) if the data logger is not collecting data and explain in the following comment section (59).

59) Enter comments regarding the calibration check and the system operation check, notes of explanation, or any discrepancies encountered.

\section{A-2.1.12 SITE DEPARTURE}

60) Check after all equipment is secured.

61) Check after the equipment is protected from the weather.

62) Check after decontamination is complete.

\section{A-2.1.13 PAGE 2 - FOOTER INFORMATION}

63) The signature of the person who entered the data on this sheet.

64) Date the data was entered.

65) The signature of the Project Manager or their designee after the sheet has been checked for completeness, accuracy and technical content.

66) The date (65) was completed 


\section{A-2.2 SERVICE FIELD DATA SHEET (SFDS)}

\section{A-2.2.1 HEADING INFORMATION}

1) Enter the sheet sequential number (e.g., 001).

2) Enter the date of the installation, in the format MM/DD/YY (e.g., 01/31/95).

3) Enter the time that this page was started, in 24-h format (HH:MM) (e.g., 12:01).

4) Enter the name(s) of the person(s) performing the service.

5) Enter the well ID (e.g., UNW-001).

6) Enter the sheet number for the IFDS done for the well.

7) Enter the well ID as per (5) for any well paired with the designated well on this SFDS.

8) Enter the sheet number for the IFDS done for a paired well.

\section{A-2.2.2 STANDING WATER LEVEL MEASUREMENT}

9) Measure and record the SWL in $\mathrm{ft}$ BMP.

10) Calculate and record SWL above MSL.

11) Enter the manufacturer of the equipment to be installed.

12) Enter the manufacturer's model number.

13) Enter the manufacturer's serial number.

14) Enter the measuring point elevation above MSL in feet.

15) Circle the measuring point used. If other, state in the blank provided.

16) Enter the maximum depth to water of the transducer operating range in $\mathrm{ft} B M P$.

17) Calculate the maximum of the transducer operating range above MSL.

18) Enter the maximum depth to water of the transducer operating range in $\mathrm{ft} B M P$ for the paired well.

19) Calculate the maximum of the transducer operating range above MSL for the pared well..

20) Enter the minimum depth to water of the transducer operating range in $\mathrm{ft} B M P$.

21) Calculate and record the minimum of the transducer operating range above MSL.

22) Enter the minimum depth to water of the transducer operating range in $\mathrm{ft}$ BMP for the paired well.

23) Calculate and record the maximum of the transducer operating range above MSL for the 
paired well.

24) Enter the measured total depth of the well in $\mathrm{ft}$ BMP.

25) Calculate and record the total well depth above MSL.

26) Enter the measured total depth of the paired well in $\mathrm{ft}$ BMP.

27) Calculate and record the total well depth above MSL of the paired well.

28) Enter the current SWL in $\mathrm{ft}$ BMP.

29) Calculate and record the current SWL above MSL.

30) Enter the current SWL in $\mathrm{ft} \mathrm{BMP}$ of the paired well.

31) Calculate and record the current SWL above MSL of the paired well.

32) Enter the instantaneous logger reading in $\mathrm{ft}$ BMP.

33) Calculate and record the instantaneous logger reading above MSL.

34) Enter the instantaneous logger reading in $\mathrm{ft}$ BMP of the paired well.

35) Calculate and record the instantaneous logger reading above MSL of the paired well.

\section{A-2.2.3 DATA LOGGER RECORDS}

36) Circle whether the test was stopped ( $\mathrm{Y}=$ yes and $\mathrm{N}=$ no).

37) If the test was stopped, record the time, in 24-h format (HH:MM).

38) Enter the test number displayed on the logger. On one channel loggers, there will be no test number, therefore, enter NA.

39) Enter the file identification number.

40) Enter the start date of the test, in MM/DD/YY format.

41) Enter the start time of the test, in 24-h format (HH:MM:SS).

42) Enter the end date of the test, in MM/DD/YY format.

43) Enter the end time of the test, in 24-h format (HH:MM:SS).

44) Enter the test interval in minutes.

45) Enter any pertinent comments as to the test setup in the space provided.

46) Enter the downloaded PC file name.

47) Circle if the downloaded file (46) was copied onto a floppy disk ( $Y=$ yes and $N=$ no).

48) Enter the analysis PC file name.

49) Circle if the downloaded file (48) was copied onto a floppy disk ( $\mathrm{Y}=$ yes and $\mathrm{N}=$ no). 
50) Circle if the data format is changed or unchanged, if changed, complete the following chart (51), (52) and (53).

51) Enter the type of data to be recorded in the column of the file structure (e.g., elevation)

52) Enter the units for the data type in (51) (e.g., feet).

53) Enter comments regarding the data logger records, notes of explanation, or any discrepancies encountered.

\section{A-2.2.4 CALIBRATION CHECK}

54) Measure and record the SWL in $\mathrm{ft}$ BMP.

55) Measure and record the SWL in $\mathrm{ft} \mathrm{BMP}$ of the paired well.

56) Take and record a data logger reading.

57) Take and record a data logger reading from the paired well.

58) Raise the transducer a specific height [e.g., one(1) foot] and record in feet.

59) Raise the transducer in the paired well a specific height [e.g., one(1) foot] and record in feet.

60) Repeat (54).

61) Repeat (55).

62) Repeat (56).

63) Repeat (57).

\section{A-2.2.5 FOOTER INFORMATION}

64) The signature of the person who entered the data on this sheet.

65) Date the data was entered.

66) The Signature of the Project Manager or their designee after the sheet has been checked for completeness, accuracy and technical content.

67) The date (28) was completed. 


\section{A-2.3 REMOVAL FIELD DATA SHEET (RFDS)}

\section{A-2.3.1 HEADER INFORMATION}

1) Enter the sheet sequential number (e.g., 001).

2) Enter the date of the removal, in the format MM/DD/YY (e.g., 01/31/95).

3) Enter the time that this page was started, in 24-h format (HH:MM) (e.g., 12:01).

4) Enter the name(s) of the person(s) performing the removal.

5) Enter the well ID (e.g., UNW-001).

6) Enter the well ID as per (5) for any well paired with the designated well on this IFDS.

\section{A-2.3.2 SFDS}

7) Circle $Y$ (yes) if the final SFDS has been completed or $N$ (no) if not.

8) Enter the final SFDS sheet number.

9) Enter comments regarding the final SFDS, notes of explanation, or any discrepancies encountered.

\section{A-2.3.3 EQUIPMENT REMOVAL AND SITE DEPARTURE}

10) Circle if all equipment and material have been removed from the well site $(Y=$ yes and $\mathrm{N}=$ no).

11) Circle if the well cap was replaced on the designated well (5) ( $Y=$ yes and $N=$ no).

12) Circle if the well cap was replaced on any paired well (6) $(Y=$ yes and $N=n o)$.

13) Circle if the wellhead was locked on the designated well (5) ( $Y=$ yes and $N=$ no).

14) Circle if the wellhead was locked on any paired well (6) $(Y=$ yes and $N=\quad$ no).

15) Circle if the well site was left cleaned $(Y=$ yes and $N=$ no).

16) Circle if an HP survey was required to leave the well site ( $Y=$ yes and $N=$ no).

17) Circle if the HP survey was completed $(\mathrm{Y}=$ yes and $\mathrm{N}=\mathrm{no})$.

18) Circle if any required decontamination was completed $(\mathrm{Y}=$ yes and $\mathrm{N}=\mathrm{no})$.

19) Enter comments regarding the equipment removal or the site departure, notes of explanation, or any discrepancies encountered. 


\section{A-2.3.4 FOOTER INFORMATION}

20) The signature of the person who entered the data on this sheet.

21) Date the data was entered.

22) The Signature of the Project Manager or their designee after the sheet has been checked for completeness, accuracy and technical content.

23) The date (22) was completed. 



\section{DISTRIBUTION}

1. H. L. Boston

2-5. R. H. Ketelle

6-9. R. R. Lee

10-12. D. M. Matteo

13-14. P. T. Owen

15. P. A. Schrandt

16. P. S. Wood

17. Central Research Library

18-19. Central ER Doc. Mgmt. Center

20-21. ORNL Doc. Mgmt. Center-RC

22. ORNL Laboratory Records Department

23. ORNL Patent Section

24. Office of Assistant Manager for Energy Research and Development, DOE Oak Ridge Operations Office, P.O. Box 2001, Oak Ridge, TN 37831-8600 
